\author{
Artykuł / Article
}

\title{
Modyfikacje systemu wspomagającego pozycjonowanie pacjenta w czasie procedury napromieniania całego ciała
}

\author{
Arkadiusz Zając ${ }^{1}$, Anna Masternak ${ }^{1}$, Stefan Dąbrowski ${ }^{1}$, \\ Jan Boruta ${ }^{1}$, Piotr Kraszewski ${ }^{1}$, Rafał Gniadek ${ }^{1}$ \\ ${ }^{1}$ Zakład Aparatury Jądrowej HITEC, Narodowe Centrum Badań Jądrowych, Otwock, Polska
}

\section{Streszczenie:}

W publikacji przedstawiono wprowadzone modyfikacje do stworzonego w Narodowym Centrum Badań Jądrowych systemu wspomagającego poprawne i powtarzalne ułożenie pacjenta podczas stosowania procedury napromieniania całego ciała.

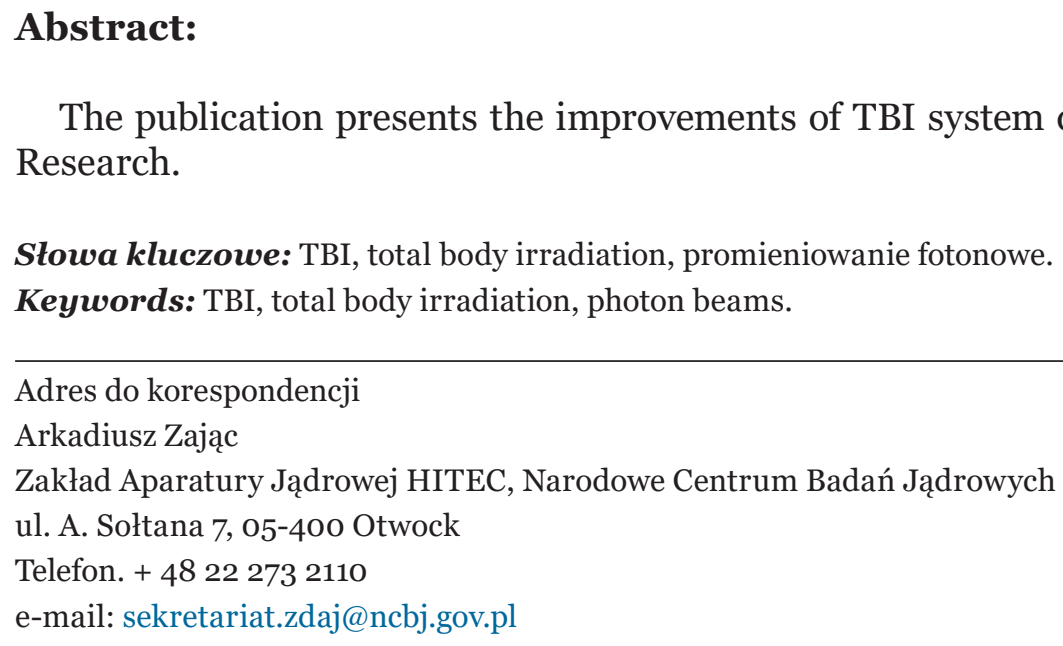
Research.

Stowa kluczowe: TBI, total body irradiation, promieniowanie fotonowe.

Keywords: TBI, total body irradiation, photon beams.

Adres do korespondencji

Arkadiusz Zając

Zakład Aparatury Jądrowej HITEC, Narodowe Centrum Badań Jądrowych

ul. A. Soltana 7, 05-400 Otwock

Telefon. + 48222732110

e-mail: sekretariat.zdaj@ncbj.gov.pl

The publication presents the improvements of TBI system developed at the National Center for Nuclear 


\section{Wprowadzenie}

Technika napromieniania całego ciała TBI (ang. Total Body Irradiation) jest szczególną procedurą radioterapeutyczną, w której całe ciało pacjenta zostaje napromienione dawką promieniowania gamma o energii megaelektronowoltów. Technika TBI jest stosowana w czasie leczenia nowotworów złośliwych, głównie chorób układu krwiotwórczego, jako element procedury przygotowania pacjenta do przeszczepu szpiku $[1,2]$. W przypadku procedury TBI, przeprowadzanej ze stosowaniem jako źródła promieniowania akceleratora liniowego, stosowana jest sekwencja napromieniania w kilku frakcjach o czasie napromieniania od 15 do 30 minut każda. Przed każdym napromienianiem pacjent jest pozycjonowany względem osi i pola wiązki promieniowania, następnie, podczas zabiegu radioterapeutycznego, pacjent leży nieruchomo [3]. Narodowe Centrum Badań Jądrowych (NCBJ) jest producentem systemu dedykowanego do leczenia techniką TBI. Pierwszy egzemplarz urządzenia produkcji NCBJ zainstalowano we wrześniu 2006 roku w Katowicach. Kolejne systemy zostały dostarczone do Dolnośląskiego Centrum Onkologii we Wrocławiu, Wielkopolskiego Centrum Onkologii im. Marii Skłodowskiej Curie w Poznaniu, Katowickiego Centrum Onkologii, Uniwersyteckiego Szpitala Dziecięcego w Krakowie i Szpitala Morskiego im. PCK w Gdyni. Oferowanemu urządzeniu w 2008 roku została przyznana nagroda „Teraz Polska”. Techniki przeprowadzenia terapii TBI opisano w podręczniku wydanym przez Międzynarodową Agencję Energii Atomowej (IAEA International Atomic Energy Agency) w 2005 roku [4]. Doświadczenia z wieloletniego stosowania systemu $\mathrm{w}$ onkologii oraz rozwój technologii materiałowych pozwoliły na wprowadzenie do systemu istotnych modyfikacji [5].W niniejszej publikacji przedstawiono zwarty opis procedury TBI z wykorzystaniem systemu opracowanego w NCBJ (Ryc. 1.) oraz wprowadzone do systemu modyfikacje i udoskonalenia zwiększające jego trwałość oraz poprawiające ergonomię jego stosowania.

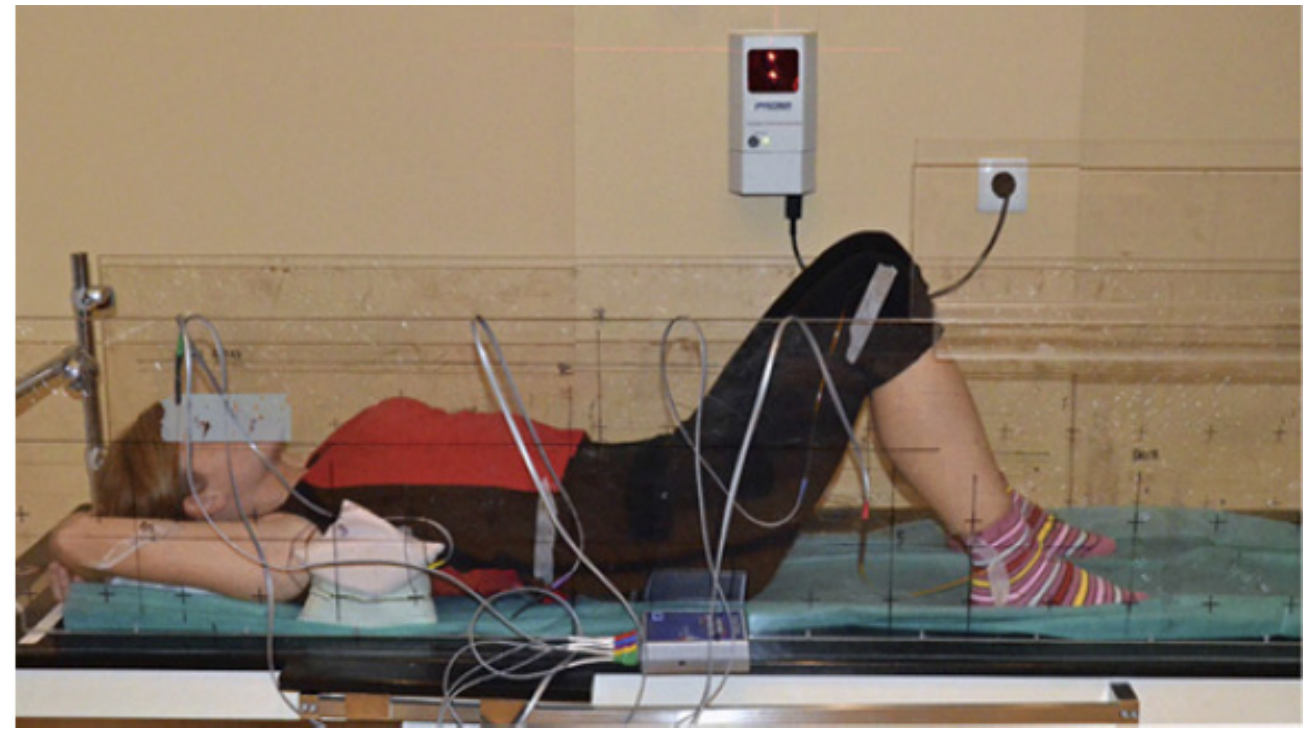

Ryc. 1. Użycie systemu pozycjonowania pacjenta produkowanego w NCBJ znacznie ułatwia przygotowanie do procedury napromieniania całego ciała TBI [5].

\section{Opis realizacji procedury TBI z użyciem systemu pozycjonowania pacjenta produkowanego w NCBJ}

W poniższym opisie zawarto dane opracowane jako zalecenia i wskazówki dla użytkowników systemu pozycjonowania opracowanego w NCBJ dla ułatwienia przeprowadzenia napromieniania metodą TBI [6]. Całkowita sumaryczna dawka podana pacjentowi w głównej osi wiązki, czyli w punkcie centrowania wiązki (PC), wynosi 1200 cGy lub 1320 cGy ze zminimalizowaniem dawki do 900 cGy w obszarze płuc (narząd krytyczny). Podstawowym założeniem dotyczącym dystrybucji dawki w całej napromienianej objętości, jest osiągnięcie jej rozkładu w granicach $\pm 10 \%$ wartości mierzonej względem danych z punktu w osi PC. Poprawę 
jednorodności rozkładu dawki na tak dużej powierzchni napromienianej pomaga uzyskać zastosowanie bolusów w postaci woreczków z ryżem.

Napromienianie pacjenta składa się z sześciu frakcji fotonowych o parametrach: energia 15 MV i moc dawki $50 \mathrm{MU} / \mathrm{min}$, gdzie:

- 4 frakcje to naprzeciwległe pola boczne $(\mathrm{SSD}=330 \mathrm{~cm}$, ustawione pole napromieniania $40 \mathrm{~cm} \times 40$ cm określone w odległości 100 cm od źródła),

- 2 frakcje to grupa czterech par naprzeciwległych pól $A P$ i $P A(\mathrm{SSD}=135 \mathrm{~cm}$, ustawione pole napromieniania $40 \mathrm{~cm}$ x $40 \mathrm{~cm}$ określone w odległości $100 \mathrm{~cm}$ od źródła),

oraz 2 frakcje wiązek elektronowych 6-15 MeV, w których zostaje napromieniony obszar ściany klatki piersiowej.

\section{Opis systemu pozycjonowania pacjenta}

System wspomagający pozycjonowanie pacjenta w czasie procedury napromieniania całego ciała oferowany przez NCBJ składa się z łóżka terapeutycznego, stołu terapeutycznego oraz laserowego centratora strzałkowego.
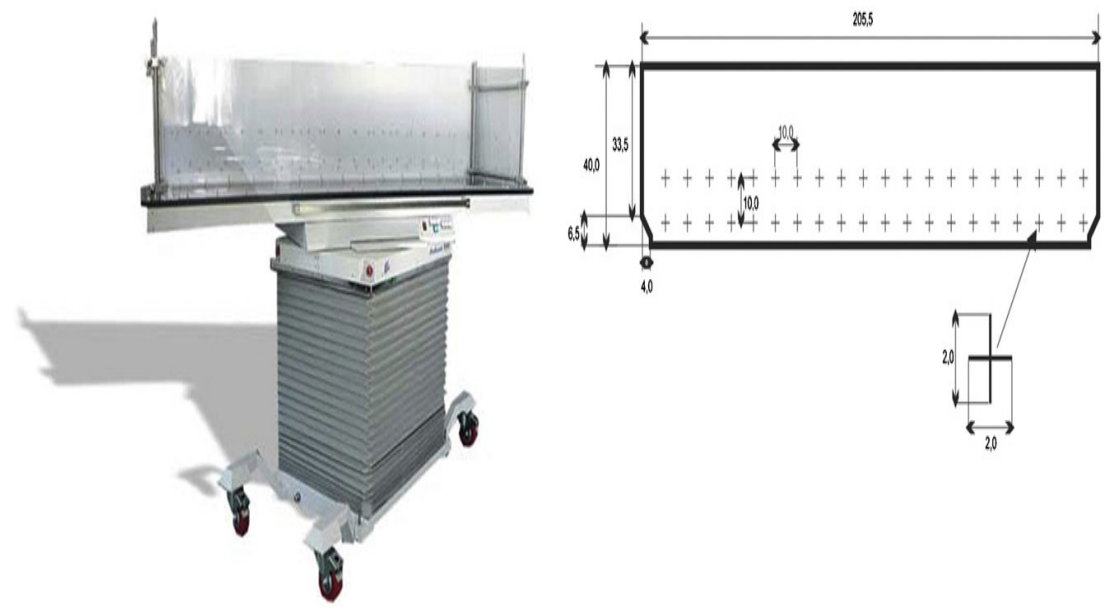

Ryc. 2. Pierwsza wersja systemu TBI wspomagającego pozycjonowanie pacjenta otrzymała w 2008 roku nagrodę „Teraz Polska”.

\section{- Łóżko terapeutyczne}

Łóżko terapeutyczne (Ryc. 2.) zostało zaprojektowane tak, aby zapewnić prawidłowe i powtarzalne ułożenie pacjenta w czasie terapii TBI. Jest to zestaw dwóch prostopadłych przeźroczystych płyt połączonych tak, aby możliwa była regulacja odległości między nimi. Taka konstrukcja pozwala na łatwe dopasowanie odległości pomiędzy płytami do rozmiarów pacjentów a w tym szczególnie pacjentów pediatrycznych. Dopasowanie odległości pomiędzy płytami do rozmiarów pacjenta rzutuje bezpośrednio na ilość użytych bolusów (takich jak na przykład woreczki z ryżem), komfort pacjenta i czas jego pozycjonowania. Na płytach naniesione są znaczniki ułatwiające powtarzalne ułożenie pacjenta względem osi wiązki.

\section{- Stół terapeutyczny}

Stół terapeutyczny (Ryc. 2.), dzięki zastosowaniu w podstawie kół, umożliwia łatwe i płynne przemieszczenie systemu TBI po powierzchni pomieszczenia terapeutycznego a nawet pozwala na przemieszczenie systemu do innej pracowni akceleratorowej. Stół wyposażony jest w silnikowe systemy regulacji jego wysokości oraz ręczne sterowanie ruchami: obrotowym, w poprzek i wzdłuż osi blatu. Możliwe jest więc skorygowanie położenia pacjenta względem pola napromieniania, nawet po zakończonym jego ułożeniu na łóżku terapeutycznym i włożeniu bolusów. Do blatu stołu jest dołączana ruchoma półka do precyzyjnego ustawienia dodatkowej osłony ograniczającej dawkę emitowaną na płuca napromienianego pacjenta. 


\section{- Strzalkowy centrator laserowy}

Centrator laserowy zainstalowany na ścianie w pomieszczeniu do radioterapii, wskazuje odległość ściany łóżka terapeutycznego od źródła wiązki promieniowania (SSD) jak i prostopadłość ułożenia ścian łóżka do osi wiązki akceleratora. Centrator jest w pełni kompatybilny z centratorami akceleratora liniowego.

\section{Parametry techniczne systemu TBI.}

Parametry techniczne systemu przedstawia tabela I.

Tabela I. Parametry techniczne systemu TBI zaprojektowanego w NCBJ.

\begin{tabular}{|c|c|}
\hline & ZAKRES RUCHU \\
\hline Zakres wysokości blatu stołu & minimalne $65 \mathrm{~cm}$ maksymalne $125 \mathrm{~cm}$ \\
\hline Rodzaj ruchu & mechaniczny \\
\hline \multirow[b]{2}{*}{ Prędkość ruchu } & ruch w górę dwie prędkości: $60 \mathrm{~cm} / \mathrm{min}$ i $180 \mathrm{~cm} / \mathrm{min}$ \\
\hline & $\begin{array}{ll}\text { ruch } \mathrm{w} \text { dół } \\
60 \mathrm{~cm} / \mathrm{min}\end{array}$ \\
\hline \multicolumn{2}{|r|}{ OBRÓT BLATU } \\
\hline Zakres obrotu & odchylenie o $15^{\circ} \mathrm{w}$ obu kierunkach \\
\hline Rodzaj ruchu & Ręczny \\
\hline \multicolumn{2}{|c|}{ PRZESUW POPRZECZNY BLATU } \\
\hline Zakres ruchu & $15 \mathrm{~cm}$ \\
\hline Rodzaj ruchu & Ręczny \\
\hline \multicolumn{2}{|c|}{ PRZESUW WZDŁUŻNY BLATU } \\
\hline Zakres ruchu & $30 \mathrm{~cm}$ \\
\hline Rodzaj ruchu & Ręczny \\
\hline \multicolumn{2}{|c|}{$\begin{array}{l}\text { BLAT STOŁU } \\
\text { Materiał: PET, kolor biały }\end{array}$} \\
\hline - wymiary blatu & $60 \mathrm{~cm} \times 225 \mathrm{~cm}$ \\
\hline - listwy boczne & stal nierdzewna \\
\hline Obciążenie użytkowe blatu & $1,35 \mathrm{kN}$ \\
\hline \multicolumn{2}{|r|}{ STEROWANIE } \\
\hline Rodzaj i miejsce sterowania: & dwa zespoły sterownicze umieszczone po obu stronach stołu \\
\hline \multicolumn{2}{|c|}{ LÓŻKO TERAPEUTYCZNE } \\
\hline Rozstaw płyt łóżka & $\begin{array}{c}\text { minimalny } 25 \mathrm{~cm} \\
\text { maksymalny } 50 \mathrm{~cm} \\
\end{array}$ \\
\hline \multicolumn{2}{|r|}{ INNE } \\
\hline ZASILANIE & zasilanie jednofazowe, $230 \mathrm{VAC} \pm 10 \%, 5 \mathrm{OHz}, \mathrm{PE}, \mathrm{o}, 75 \mathrm{kVA}$ \\
\hline MASA STOEU & $500 \mathrm{~kg}$ \\
\hline
\end{tabular}




\section{Modyfikacje}

Zebrane doświadczenia z wieloletniej eksploatacji systemu, wynikające również z uwzględnienia wpływu promieniowania poza osią wiązki [7] oraz postęp techniczny w zakresie nowych materiałów pozwoliły na wprowadzenie wymienionych poniżej zmian w systemie TBI produkcji NCBJ.

\section{- Łóżko terapeutyczne}

Dotychczas stosowane płyty łóżka terapeutycznego wykonane były z plexiglasu. Płyty te mają ograniczoną wytrzymałość mechaniczną spadającą z upływem okresu użytkowania, potrafią pękać, co utrudnia a nawet uniemożliwia ich stosowanie. Zastąpiono je płytami z poliwęglanu litego: mają one porównywalne właściwości do plexiglasu w wiązce promieniowania fotonowego, ale charakteryzują się one dużo lepszymi właściwościami mechanicznymi, w tym są zdecydowanie bardziej odporne na destrukcyjne oddziaływanie promieniowania jonizującego.

Przeprowadzony wywiad u klientów pokazał problemy z elementami systemowymi mocowania płyt łóżka, które po kilkuletnim okresie użytkowania w wiązce promieniowania jonizującego odkształcają się plastycznie, co powoduje zakleszczanie się prowadnic i utrudnione operowanie zmianą rozstawu płyt łóżka terapeutycznego. Zdecydowano o zastosowaniu materiału o wyższej granicy sprężystości.

\section{- System sterowania}

Zmodernizowano zespoły sterownicze stołu (Ryc. 3). Dotychczasowe, pojedyncze przyciski sterujące zastąpiono sześciokolorową podświetlaną klawiaturą membranową, wygląd stołu przybrał nowoczesny charakter, jednocześnie została poprawiona jego ergonomia. Rozwiązanie ułatwiło też obsługę urządzenia w słabo oświetlonym pomieszczeniu, na przykład z włączonym centratorem laserowym.

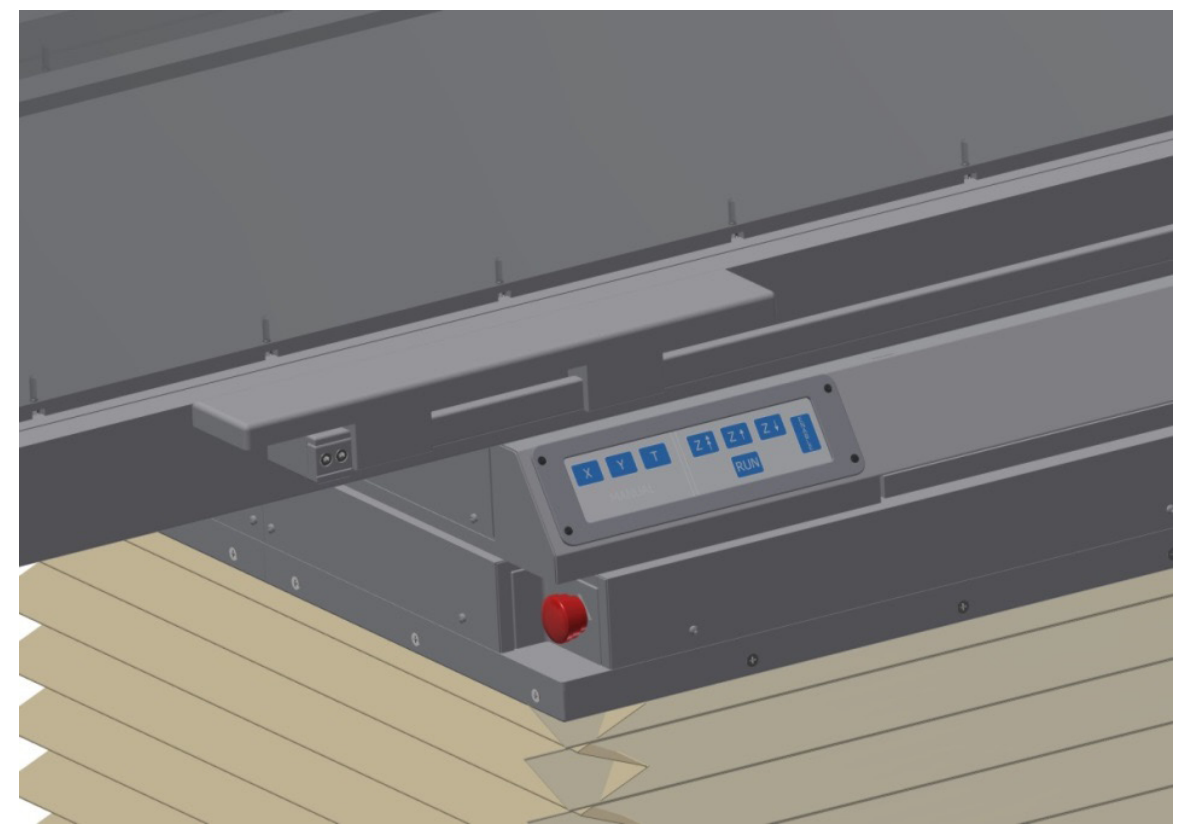

Ryc. 3. Zespół sterowniczy stołu Polkam TBI.

Udoskonalono również układ sterowania poprzez zastosowanie nowoczesnego, programowalnego falownika skalarnego, który umożliwia wybór predefiniowanej prędkości obrotowej lub płynną jej regulację. Wbudowana kompensacja poślizgu silnika indukcyjnego gwarantuje precyzyjną nastawę prędkości, a w połączeniu z regulatorem PID (proporcjonalno-całkująco-różniczkujący) i zastosowaną kompensacją momentu obrotowego, zależną od rodzaju obciążenia, falownik zapewnia płynny rozruch i hamowanie bez 
szarpnięć w niezależnie zadawanym czasie. Falownik posiada wbudowany moduł hamowania dynamicznego do bezpośredniego podłączenia rezystora hamowania, co zmniejsza wymaganą przestrzeń montażową.

Zastosowany układ hydrauliczny podnoszenia stołu, podczas wieloletniej eksploatacji w Centrach Onkologii, wykazał się dużą niezawodnością, dlatego też nie dokonano żadnych modyfikacji tej konstrukcji.

\section{Podsumowanie}

Technika napromieniania całego ciała pacjenta jest powszechnie stosowana jako jedna $\mathrm{z}$ procedur radioterapeutycznych dedykowanych dla ściśle określonej grupy chorób [8].

Rozwiązania zastosowane w systemie TBI, produkowanym przez NCBJ, wspomagającym pozycjonowanie pacjenta w czasie procedury napromieniania całego ciała, pozwalają na łatwe, powtarzalne i szybkie ułożenie pacjenta względem pola i osi napromieniania. Mobilność rozwiązania oraz zakresy przesuwu blatu zaprojektowano z myślą o łatwym przemieszczaniu pacjenta z łóżka szpitalnego na łóżko terapeutyczne oraz na stoły innych urządzeń terapeutycznych. Zastosowanie wyżej wymienionych rozwiązań daje możliwość planowania leczenia $\mathrm{z}$ wykorzystaniem systemu planowania $3 \mathrm{D}$ oraz weryfikacji położenia pacjenta wraz z obszarami zainteresowania określonymi za pomocą tomografii komputerowej.

Podsumowując system TBI produkcji NCBJ charakteryzuje się:

- możliwością ułożenia pacjenta bez konieczności używania zewnętrznych systemów wspomagających,

- dokładnym ustawieniem wysokości względem osi wiązki promieniowania w znaczącej odległości od źródła promieniowania,

- precyzyjnym ustawieniem prostopadłości stołu względem wiązki promieniowania,

- precyzyjnym ustawieniem pacjenta względem osi wiązki promieniowania,

- mobilnością (możliwość przemieszczania do innej pracowni).

NCBJ poświęciło dużo uwagi przy wyborze materiałów, z których wykonany jest system, aby zapewnić jego wysoką trwałość i odporność na promieniowanie. System jest przystosowany również do sterylizacji.

\section{Bibliografia}

[1] Baker KS, Leisenring WM, Goodman PJ, Ermoian RP, Flowers ME, Schoch G, et al. Total Body Irradiation Dose and Risk of Subsequent Neoplasms Following Allogeneic Hematopoietic Cell Transplantation. Blood 2019; 133 (26):2790-2799.

[2] Giebel S, Miszczyk L, Ślosarek K, Moukhtari L, Ciceri F, Esteve J, et al. Extreme Heterogeneity of Myeloablative Total Body Irradiation Techniques in Clinical Practice: A Survey of the Acute Leukemia Working Party of the European Group for Blood and Marrow Transplantation. Cancer 2014; 120 (17):2760-2765.

[3] Quast U. Whole Body Radiotherapy: A TBI-Guideline. J Med Phys 2006; 31 (1): 5-12.

[4] Podgorsak EB. Radiation Oncology Physics: A Handbook for Teachers and Students. International Atomic Energy Agency 2005, Vienna.

[5] Kawa-Iwanicka A, Łobodziec W, Dybek M, Nenko D, Iwanicki T. Dose Distribution Homogeneity in Two TBI Techniques-Analysis of 208 Irradiated Patients Conducted in Stanislaw Leszczynski Memorial Hospital, Katowice. Reports of Practical Oncology \& Radiotherapy 2012; 17 (6):367-375.

[6] Kawa-Iwanicka A. Technika napromieniania całego ciała pacjenta (Total Body Irradiation- TBI) w Zakładzie Radioterapii Szpitala im. S.Leszczyńskiego w Katowicach. Materiały niepublikowane, dołączone do dokumentacji technicznej urządzenia. Zakład Aparatury Jądrowej Instytut Problemów Jądrowych im. Andrzeja Sołtana 2007.

[7] Piotrowski T, Adamska K, Malicki J. Effect of Scattered Radiation in the Total Body Irradiation Technique: Evaluation of the Spoiler and Wall Dose Component in the Depthdose Distribution. Nukleonika 2007; 52(1):153-158.

[8] Karolak A. Procedura napromieniania całego ciała w Wielkopolskim Centrum Onkologii. Zeszyty Naukowe WCO, Letters in Oncology Science 2016;13(1):18-23. 